https://doi.org/10.46344/JBINO.2020.v09i5b.12

\title{
COMPARATIVE CLINICAL EVALUATION OF RASASINDHOOR AND SUVARNAKSHIRI ROOT IN THE MANAGEMENT OF KITIBHKUSHTA VIS-À-VIS PSORIASIS
}

\author{
Dr. Manoj Kulkarni ${ }^{1} \&$ Dr. Sharvari Kulkarni²
}

Associate professor,Department of rasashastra- bhaishajya-kalpana,Ashwin Ayurved college, manchi Hill.

Professor, department of kayachikitsa, Eva college of Ayurved, Zanjamer road, supedi, tal... Dhortagi, Gujarat

\begin{abstract}
Ayurvedic science is being lucratively dealing with skin disorder comprehensively since ancient era to present scenario. People often faces foremost problem of skin diseases in day today's life. The main causative factors behind skin diseases are various pollens, irritants allergens, fast foods, irregular meal etc. These causes related modified lifestyle of human being further vitiated by Tridosha to form various skin disorders like SLE, Eczema, Lichaen plannus are seen wider scale today. The vitality of skin again play a crucial role in the pathogenesis of diverse skin diseases. They instigate with small eruption over surface \& very soon spread over body involving deeper tissue. Treating such disease is exigent. Skin diseases are varied and complicated. The management of skin diseases with herbomineral drugs is very effective. Along with this, some mineral drugs has augmenting action with some herbal drugs. In present study the Swarnakshiri has been compared to rule out clinical efficacy Rasasindhoor as augmenting agent as well as therapeutic component in management of Kitibhbhkushta.
\end{abstract}

Keywords: Kitibhkushta, Suvarnakshiri Root, Rasasindhoor. 


\section{INTRODUCTION}

Ayurveda is an ancient Indian Science. The theme of Ayruveda is to maintain the proper health and to cure the disease of human being. The entire science of Ayurveda has been framed upon "Trisutra's" (Hetu, Linga and Aushadha). Aushadha is the most important as it is helpful for the alleviation of disease as well as for the maintenance and promotion of good health.

From the historical point of view, upto the $7^{\text {th }}$ century, it may be said that herbal preparation were used for curative purposes (i.e. upto the period of Asthanga Hridaya). After this period the uses of minerals and metals started for therapeutic purpose. As these metal and mineral could not be used orally in the crude form, they found it necessary to have specialized technical knowledge for converting minerals and metals into biologically effective form. Hence the concept of separate branch of learning known as Rasashastra including the concept of Rasashala and Rasavaidya emerged in the field of Ayurveda. The word Rasa denotes numerous things including the mercury, which has been extensively used in the preparation of potent Kupipakva Rasayana and Rasapottali.

Ras-shastra is the branch of Ayurveda, which deals with pharmaceutical and therapeutic scope of the medical product of mercury minerals and metals, which are characterized by the smaller doses instant effect and long durability.

Thus Ras-shastriya preparation plays an important and vital role in curing the allying human being. So in the globalization of Ayurveda world is looking at herbomineral formulation for its magical results. Metallic preparation is used irrespective of Dosha, producing the disease, the person and deshas. This gave a very rude shock to the physician belonging to schools of Atreya.

Charak and Sushruta samhita also indicate the use of some primary metals like gold, silver, copper and iron and their alloys including bronze and brass.

The entry of trace element in the armametrium of therapy against many diseases is as old as human civilization itself. Since time immemorial man sought the help of their element in the form of minerals and metals for the alleviation of his ailment as well as to maintain positive health along with medicinal herbs and animal products.

To quote few examples are the role of gold as immune promoter agent, Iron in iron deficient anemia etc. Rasavaidyas had sound knowledge regarding the pharmaceutical processing of plant and animal products. They were a step ahead in the aspects of minerals and metallic products at the time of Samhita i.e. between $600 \mathrm{BC}$ to $100 \mathrm{AD}$. As the knowledge of chemistry and chemical procedures advanced he was able to shape and equip himself with appropriate technique that enabled him to give birth to a branch of 
pharmaceutics called Rasa-shastra. Rasshastra has been specially contributed to prepare medicines by using different pharmaceutical process. The world Rasa denotes numerous things including mercury which has extensively used in the Rasa-preparations.(1)

The drugs are required in lesser doses are tasteless hence can be easily administered and it gives good health in short duration.

For time to time number of Reasearches have been done in this field as to assess the therapeutic properties of the drugs given in our texts. It has become mandatory now as the science is evolving around the world. Now days due to modern lifestyle people are facing many health problems. The aetiology of few is unknown. Due to low immunity, problem becomes worse. Here comes our role to identify these diseases and find a cure. For this researches are must. Our ancient Acharyas have laid down some parameters to remain health and had discovered some wonderful drugs to get rid of diseases. But now in the present era there is a need to revaluate, reexamine these drugs challenge their validity, standardize them by modern means and then accept and reject them in short period. Research need to be done in the known facts and to bring them into a new light. Also by doing this the drug having potential can be easily made available.

People often face major problems of skin. And in some others it is long persisting. It is more of a social stiama as it is visible to everyone. About 20-30\% have some form of skin disorders needing medical attention. In todays life, majority of skin diseases are caused due to various pollens, irritants, allergens, fast foods, irregular meal and other. Autoimmunity is another upcoming cause which is rapidly taking over the body causing various disorder. Skin diseases like SLE. eczema and lichen plannus are seen on a wider scale today. They begin with small eruption over the surface and very soon spread involving deeper tissues. Treating such disease is challenging. Kitibha Kustha / Psoriasis is one of such disease which mainly involves limbs but can occur even on genitals, face and trunk. Modern Science does not have any answer for the psoriasis. As in Ayuryeda, the disease caused by Virodhi Ahar-Vihar and even by krimi. The main symptoms i.e. the mean of psoriasis is to psora to "itch". The person suffering from the iteming becomes totally demolaralized because psoriasis appears on the surface. Such is its impact and thus it becomes all the more important to find a treatment that can cure him of his stigma.

Treating psoriasis is found to be a challenging problem in front of the medical fraternity. Firstly to identify the cause i.e. unknown or other in itself is challenge and once this is done to manage the diseases is another big step. In modern medicine it is treated with steroids which only gives symptomatic, temporary relief with steroids. And later on the disease tends 
to occur again with same or even worse force. Skin is the mirror of a person's personality. Anything involving it affects the person mentally, as it is more of social stigma being visible to all. Hence a remedy which will eradicate the cycle of recurrence is needed. For this we need not invert something new, just need to dig our treasure where our Ayurvedacharyas have given all remedies but which due to ignorance and negligence have fallen back, it is now time to bring it back to the world.

Skin disease are varied and complicated. If research is conducted in Ayurveda and pains are taken we can do enough good to the suffering humanity not only in India but also throughout the world to relive the patient from and anguish caused by the disease. Psoriasis is a dangerous and troublesome disease, but there are suitable an enough resources at our disposal for treatment.

In present study Rasasindoora IS research drug with Swarnakshiri. Rasasindoora is the Sagandha kupipakva Rasayana with augumenting property. Rasasindoora when given with Herbal Drugs increases the drug activity, minimizes the dose with instant relief.

Swarnakshiri is the herb having Kusthaghna property. The drug is mentioned in Rasa-ratnasamuchaya and also used by the vaidyas traditionally in the skin disorder. The action of the swarnakshiri is Bhedaka and raktadoshaghna.
Hence Swarnakshiri having Kusthaghna property was selected alone and along with Rasasindoora and Rasapottali to assess the efficacy on Kitibha kushtha.

\section{AIMS AND OBJECTIVES :}

1) To evaluate efficacy of Suvarnakshiri root choorna in the management of Kitibhkushta (Psoriasis).

2) To evaluate the efficacy of Suvarnakshiri root choorna along with Rasasindhoor in the management of Kitibhkushta (Psoriasis).

\section{HYPHOTHESIS}

1) $\mathrm{HO}$

2) $\mathrm{Hl}$

\section{MATERIAL AND METHODS}

\section{Collection of Patient:}

The entire patients visiting as a Kitibhkushta in OPD \& IPD of Rasashastra department has 
been scrutinized as per exclusion and inclusion criterion and divided in two groups randomly. The randomization chart has been utilized for the appropriate randomization.

\section{Diagnostic Criterion:}

The classical signs and symptoms of Kitibhkushta (Psoriasis) like Aswedanam ( Localized absence of Swaeing), Vivarnata (Discoloration), Kandu (Itching), Scaleing - Manadlam (Round patches of Discoluration) etc

\section{Criteria for selection of patient}

: Having classical symptom of Kitibhakustha,

: Age group 15-70 years.

: Any sex, any religion and any class.

Criteria for exclusion : Age group below 15 and above $\quad 70$ years.

: Known case of cardiac disease and diabetes.

: Pregnant woman, H. I. V. patients.

\section{Intervention:}

\section{Suvarnakshiri Roota Choorna}

\section{Botanical Classification of}

\section{Swarnakshiri :-}

Kingdom

-- Plantae

Division

Magnoliophyta

Sub-Division

Class

Manoliopsida

Sub-Class

Family

Papaveraceae

Genus

-- Argemone

Species

-- Mexicana

Latin Name

Argemone mexicana Linn.

\section{Rasasindhura}

Name

Kalpana

Ingredients

\section{Group A:}

\section{Name of Drug}

- Rasasindhura

- Rasapottali Parada (Mucury) Gandhaka (Sulphar)

Suvarnakshiri Roota Choorna with Rasasindhura : Oral

Route

:

Choorna (Powder) 
Frequency

Anupana (Vehicle )

No of Days

Diet
: Twice a daily

: Luke warm

water

: 41 days

: The diet to be avoided in Kustha disease was strictly followed.

Obsevations

No. of Patients
: Weekly
Frequency

Anupana (Vehicle)

No of Days

Diet
: Twice a daily

: Luke warm water

: 41 days

: The diet to be avoided in Kustha disease was strictly followed. : Weekly

Obsevations

No. of Patients

$: 40$

\section{Group B:}

Name of Drug

: Suvarnakshiri Roota

Choorna without

Rasasindhura

Route

Doses form

Dose
: Oral

Choorna (Powder)
Criteria for assessment -

Patients were examined weekly during the treatment. Case record form was filled up and changes noted accordingly. To note down the relief sign and symptoms they were graded as follows -
: $1 \mathrm{gm}$

Suvarnakshiri

root choorna

\begin{tabular}{|c|c|c|c|c|c|}
\hline Signs & $\mathbf{0}$ & 1 & 2 & 3 & 4 \\
\hline ASVEDAN & Normal & Improvement & $\begin{array}{c}\text { Present in few } \\
\text { lesion }\end{array}$ & $\begin{array}{c}\text { Present in all } \\
\text { lesion }\end{array}$ & All over Body \\
\hline $\begin{array}{c}\text { MAHAVA } \\
\text { (Diameter of } \\
\text { lesion) }\end{array}$ & Normal & $1 \mathrm{~cm}$ to $2 \mathrm{~cm}$ & $\begin{array}{c}2 \mathrm{~cm} \text { to } \\
3 \mathrm{~cm}\end{array}$ & $3 \mathrm{~cm}$ to $4 \mathrm{~cm}$ & $\begin{array}{c}\text { More than } \\
4 \mathrm{~cm} .\end{array}$ \\
\hline SCALING & No Scaling & $\begin{array}{l}\text { Scaling off in } \\
15-30 \text { days }\end{array}$ & $\begin{array}{l}\text { Scaling off in } \\
7-15 \text { days }\end{array}$ & $\begin{array}{c}\text { Scaling off in 5- } \\
7 \text { days }\end{array}$ & $\begin{array}{c}\text { Scaling off in } \\
1-5 \text { days }\end{array}$ \\
\hline KANDU & No Kandu & $\begin{array}{c}\text { Mild or } \\
\text { occasional }\end{array}$ & Off and On & $\begin{array}{c}\text { Continuous } \\
\text { without } \\
\text { disturbed sleep }\end{array}$ & $\begin{array}{c}\text { Continuous } \\
\text { with disturbed } \\
\text { sleep }\end{array}$ \\
\hline VIVARNATA & Normal & Near to normal & $\begin{array}{c}\text { Blanching red } \\
\text { colour }\end{array}$ & $\begin{array}{l}\text { Red colour }+ \\
\text { subcutaneous }\end{array}$ & $\begin{array}{c}\text { Blackish red } \\
\text { colour }\end{array}$ \\
\hline
\end{tabular}




\begin{tabular}{|c|c|c|c|c|c|}
\hline DAHA & No daha & Mild daha & Moderate daha & Severe daha & $\begin{array}{c}\text { Severe daha } \\
\text { affecting sleep }\end{array}$ \\
\hline MANDALA & $\begin{array}{c}\text { No } \\
\text { elevation }\end{array}$ & $\begin{array}{c}\text { Slight elevation } \\
\text { which not felt }\end{array}$ & $\begin{array}{c}\text { Elevation felt } \\
\text { but depressed } \\
\text { in middle }\end{array}$ & $\begin{array}{c}\text { Elevation in all } \\
\text { lesion but soft }\end{array}$ & $\begin{array}{c}\text { Elevation in } \\
\text { all lesion but } \\
\text { hard }\end{array}$ \\
\hline
\end{tabular}

\section{Observations and Results}

The observation and their inferences are -

1. according to Age -

\begin{tabular}{|c|c|c|c|c|c|}
\hline \multirow{3}{*}{ Sr.No } & \multirow{2}{*}{ Age } & \multicolumn{2}{|c|}{ Group A } & \multicolumn{2}{c|}{ Group B } \\
\cline { 2 - 6 } & No. of Patients & $\boldsymbol{\%}$ & No. of Patients & \% \\
\hline 2 & 1 to 20 & 2 & 5 & 1 & 2.5 \\
\hline 3 & 21 to 40 & 12 & 30 & 18 & 45 \\
\hline 4 & 41 to 60 & 22 & 55 & 19 & 47.5 \\
\hline & 61 to 80 & 4 & 10 & 2 & 5 \\
\hline
\end{tabular}

In this group A shows 41 to 60 age group $55 \%$ and group B is $47.5 \%$.

\section{According to Sex -}

\begin{tabular}{|c|c|c|c|c|c|}
\hline & & \multicolumn{2}{|c|}{ Group A } & \multicolumn{2}{c|}{ Group B } \\
\hline Sr.No & Sex & No. of Patients & \% & No. of Patients & \% \\
\hline 1 & Male & 26 & 65 & 31 & 77.5 \\
\hline 2 & Female & 14 & 35 & 9 & 22.5 \\
\hline & Total & 40 & 100 & 40 & 100 \\
\hline
\end{tabular}

In this group A having maximum no. of male patients (65\%), group B also having maximum no. of male patients $(77.5 \%)$,

\section{According to Religion -}

\begin{tabular}{|c|c|c|c|c|c|}
\hline \multirow{2}{*}{ Sr.No } & \multirow{2}{*}{ Religion } & \multicolumn{2}{|c|}{ Group A } & \multicolumn{2}{c|}{ Group B } \\
\cline { 3 - 6 } & & No. of Patients & \% & No. of Patients & \% \\
\hline 1 & Hindu & 34 & 85 & 33 & 82.5 \\
\hline 2 & Muslim & 6 & 15 & 7 & 17.5 \\
\hline & Total & 40 & 100 & 40 & 100 \\
\hline
\end{tabular}


In this Hindu patients are more predominant than Muslim patients. In group A, 85\% are Hindu patients. In group B, $82.5 \%$ patients are Hindu. In group C, $65 \%$ patents are Hindu.

\section{According to Diet -}

\begin{tabular}{|c|c|c|c|c|c|}
\hline \multirow{2}{*}{ Sr.No } & \multirow{2}{*}{ Type of Diet } & Group A & \multicolumn{2}{c|}{ Group B } \\
\cline { 3 - 6 } & Vegetarian & No. of Patients & $\%$ & No. of Patients & $\%$ \\
\hline 1 & Nonvegetarian & 23 & 57.5 & 22 & 55 \\
\hline 2 & Total & 17 & 42.5 & 18 & 45 \\
\hline & 40 & 100 & 40 & 100 \\
\hline
\end{tabular}

According to Diet, in group A, 57.5\% are vegetarian. In group B the percentage is $55 \%$.

\section{According to koshtha-}

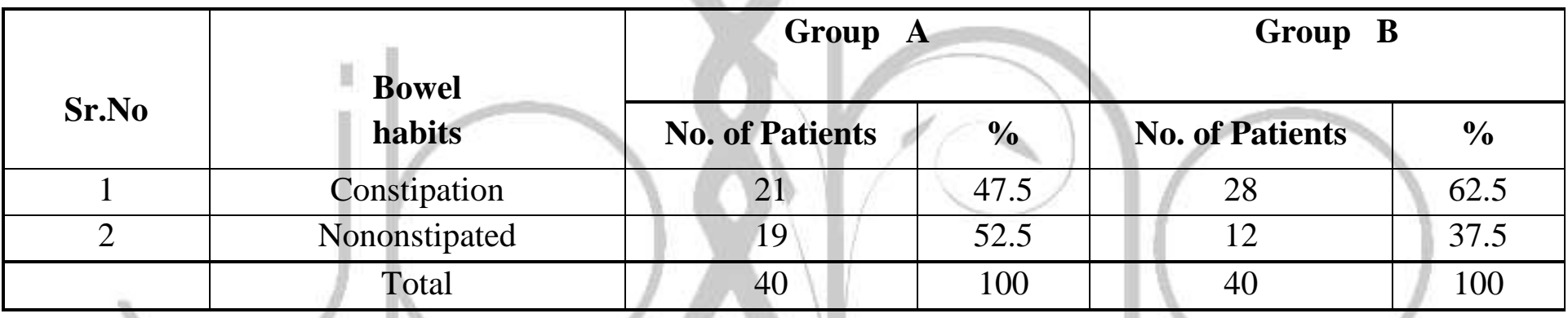

In group A, $52.5 \%$ patients dose not have constipation. While in group B, 62.5\% patient having constipation. In group C, 55\% patient having constipation. In group A, 47.5\%, group B, $62.5 \%$.

\section{According to Stress -}

\begin{tabular}{|c|c|c|c|c|c|}
\hline \multirow{2}{*}{ Sr.No } & \multirow{2}{*}{ Stress } & \multicolumn{2}{|c|}{ Group A } & \multicolumn{2}{c|}{ Group B } \\
\cline { 3 - 6 } & Absent & No. of Patients & \% & No. of Patients & \% \\
\hline 1 & Minimum & 12 & 30 & 12 & 30 \\
\hline 2 & Maximum & 20 & 20 & 12 & 30 \\
\hline 3 & Total & 40 & 50 & 16 & 40 \\
\hline & & 8 & 100 & 40 & 100 \\
\hline
\end{tabular}

According to Stress, group A shows 50\% patient suffering from maximum Stress. In group B 40\% patients, suffering from maximum Stress. 


\section{According to Addiction Distribution -}

\begin{tabular}{|c|c|c|c|c|c|}
\hline \multirow{3}{*}{ Sr.No } & \multirow{3}{*}{ Addition } & \multicolumn{2}{|c|}{ Group A } & \multicolumn{2}{c|}{ Group B } \\
\cline { 3 - 6 } & Smoking & 6 & 15 & 5 & No. of Patients \\
\hline 1 & Alcohol & 4 & 10 & 7 & 12.5 \\
\hline 2 & Tobacco & 10 & 25 & 12 & 30 \\
\hline 3 & No Habits & 20 & 50 & 16 & 40 \\
\hline 4 & Total & 40 & 100 & 40 & 100 \\
\hline
\end{tabular}

According to Addiction in group A the 50\% having no addiction. In group B the percentage is $40 \%$..

\section{Result.}

\begin{tabular}{|c|c|c|c|c|c|c|c|c|c|}
\hline Sign/Sym & Group & BT & AT & $\mathrm{SD}$ & SE & $\begin{array}{c}\text { 't' } \\
\text { VAIUE }\end{array}$ & $\mathrm{P}$ value & Result & In $\%$ \\
\hline \multirow{2}{*}{ Aswedanam } & A & 2.85 & 1.77 & 1.02 & 0.16 & 9.6 & $\mathrm{P}<0.001$ & H SIG & 53.26 \\
\hline & B & 2.65 & 1.37 & 1.04 & 0.16 & 7.68 & $\mathrm{P}<0.001$ & M SIG & 48.30 \\
\hline \multirow[t]{2}{*}{ Kandu } & $\mathrm{A}$ & 2.9 & 0.85 & 1.1 & 0.17 & 11.34 & $\mathrm{P}<0.001$ & H SIG & 53.26 \\
\hline & B & 2.7 & 1.37 & 1.08 & 0.17 & 7.83 & $\mathrm{P}<0.001$ & M SIG & 49.25 \\
\hline \multirow{2}{*}{$\begin{array}{l}\text { Diameter of } \\
\text { Patches }\end{array}$} & A & 2.77 & 1.32 & 0.8 & 0.13 & 11.06 & $\mathrm{P}<0.001$ & H SIG & 56.76 \\
\hline & B & 2.65 & 1.37 & 1.04 & 0.16 & 7.68 & $\mathrm{P}<0.001$ & M SIG & 41.07 \\
\hline \multirow[t]{2}{*}{ Scal } & A & 2.5 & 1 & 0.8 & 0.12 & 11.65 & $\mathrm{P}<0.001$ & H SIG & 59.78 \\
\hline & B & 2.97 & 1.9 & 1.11 & 0.17 & 6.08 & $\mathrm{P}<0.001$ & M SIG & 36.62 \\
\hline \multirow[t]{2}{*}{ Vivarnata } & A & 2.7 & 1.25 & 0.77 & 0.12 & 12.04 & $\mathrm{P}<0.001$ & H SIG & 64.52 \\
\hline & B & 2.72 & 1.7 & 0.98 & 0.15 & 6.56 & $\mathrm{P}<0.001$ & M SIG & 37,90 \\
\hline \multirow[t]{2}{*}{ Mandala } & $\mathrm{A}$ & 2.87 & 1.4 & 0.8 & 0.12 & 11.57 & $\mathrm{P}<0.001$ & H SIG & 63.44 \\
\hline & B & 2.9 & 1.9 & 1.33 & 0.2 & 4.49 & $\mathrm{P}<0.001$ & M SIG & 34.48 \\
\hline
\end{tabular}

\section{DISCUSSION AND CONCLUSION}

It was great interest to assess the above said properties in both formulations. The Ideal method for assessment of Rasa Preparation is the Clinical Study. Study was conducted at Smt. K. G. M. P. Ayurvedic
Hospital in 40 patient of Kitibha Kushta diagnosed as per criteria of diagnosis. The observation and inferences are -

1. Psoriasis is more common in age group 41 to 60 yrs. (45.90\%). 
2. It is more common in male patients. The ratio is $70: 30$.

3. No. of Hindu Patients are $77 \%$ while $33 \%$ are Muslim Patients.

4. $53 \%$ Patients were Vegetarian and rest $47 \%$ were of mix food habits.

5. In order to age incidence, maximum cases were found between 14-60 yrs. of age. The youngest patient in this study was of 20 years and the oldest was 70 years. The minimum incidence was recorded in age group of 21 to 30 years.

6. According to Bowel Habits 55\% Patients are Irregular Bowel Habits while $45 \%$ Patients are Regular Bowel Habits.

7. The $43 \%$ Patients shows Maximum Stress.

8. The $39 \%$ Patients having No Addiction while $61 \%$ Patients having Addiction like smoking, drinking and tobacco chewing.

9. There Major Groups were made for comparative analysis viz. A, B

10. The name of the Groups as given below -
Group A :
Swarnakshiri-

Rasasindoora

Churna

Group B : Swarnakshiri

\section{CONCLUSION}

Ayurveda has its own research methodology which is unquestioned in the current conventional systems of knowledge, technology, molecular biology and statistics. The study was done in the postgraduate department of Rasashastra.

Psoriasis is one alarming and incurable entity which is seeking a root care. Number of researches has been done but yet success is not achieved. This indicates need of few management of psoriasis. Though study of the disease revealed the factors like constipation, stress, Dosh-Dushya samurcchana responsible for the pathogenesis. The factors are deep seated and difficult to check.

Two selected Rasa Formulations were prepared and developed as per basic principle of Rasashastra viz. each component drug was developed with antipsoriasis property by using process of shodhana, mardana, bhavna. Standardization which is essential for any drug before commencing clinical use or manufacturing, was done in most accepted fashion. The data generated will be helpful for its quality control and standardization of other herb mineral preparations which is often not done satisfactorily by the manufacturers.

Open random clinical study of 80 patients of psoriasis showed the efficacy of the drugs over usual line of treatment given in institute. Among the various parameter, the The administration of Rasasindoora with swarnakshiri churna shows drastic results in the scaling, kandu, 
twakvaivarnya. There is no side effects recorded in this drug.

\section{CLINICAL STUDY -}

For the Clinical Study Two groups were made -
The Distribution of Group -

Group A : Swarnakshiri--

Rasasindoora

Group B : Swarnakshiri Churna

\section{Upashaya in Symptom in Rassindoora with-swarnakshiri}

\begin{tabular}{|c|l|c|c|l|}
\hline \multirow{2}{*}{$\begin{array}{c}\text { Sr. } \\
\text { No. }\end{array}$} & \multirow{2}{*}{ Symptoms } & \multicolumn{2}{|c|}{$\begin{array}{c}\text { No. of gradation } \\
\text { all patients }\end{array}$} & \multirow{2}{*}{ Upashaya in Percentage. } \\
\cline { 3 - 5 } & & BT & AT & \\
\hline 1. & Aswedan & 44 & 19 & $56.81 \%$ \\
\hline 2. & Kandu & 45 & 17 & $62.22 \%$ \\
\hline 3. & Diameter & 42 & 17 & $59.05 \%$ \\
\hline 4. & Scaling & 41 & 14 & $65.08 \%$ \\
\hline 5. & Vivarnata & 45 & 15 & $66.66 \%$ \\
\hline 6. & Mandala & 46 & 18 & $60.87 \%$ \\
\hline
\end{tabular}

According to table, the maximum percentage of Upashaya group I is in the Vivarnata (66.66\%) also in the scaling $(65.80 \%)$ and minimum also in the Scaling $(65.80 \%)$ and minimum in the Aswedan $(56 . \%)$

\section{Group B Upashaya in Symptom in Swarnakshiri -}

\begin{tabular}{|c|l|c|c|l|}
\hline \multirow{2}{*}{$\begin{array}{c}\text { Sr. } \\
\text { No. }\end{array}$} & \multirow{2}{*}{ Symptoms } & \multicolumn{2}{|c|}{$\begin{array}{c}\text { No. of gradation } \\
\text { all patients }\end{array}$} & \multirow{2}{*}{ Upashaya in Percentage. } \\
\cline { 3 - 5 } & & BT & AT & \\
\hline 1. & Aswedan & 106 & 55 & $48.30 \%$ \\
\hline 2. & Kandu & 109 & 55 & $49.25 \%$ \\
\hline 3. & Diameter & 112 & 66 & $41.07 \%$ \\
\hline 4. & Scaling & 119 & 76 & $36.02 \%$ \\
\hline 5. & Vivarnata & 109 & 68 & $37.90 \%$ \\
\hline 6. & Mandala & 117 & 79 & $34.48 \%$ \\
\hline
\end{tabular}

The Swarnakshiri group III majorly acts on the Kandu (49.25\%) and on Aswedana (48.30\%) and less on Mandala (34.48\%).
Rasasindoora groups proved to be better result than its counter part Swanakshiri 
$>$ All the groups gave complete results from 'Kandu'.

$>$ All the groups shows $90 \%$ relief from the Twakvaivarnya and scaling. Daha and Mandala with few exceptions

\section{REFERENCES}

1.Rasendrasarsangraha of acharya krushnagopal bhatt $1 / 5$

2.Rasa-ratnasamucchhya of Shree Vaghbhatacharya edited with Suratnojivla hindi commentary by Kaviraj Shree Ambikadatta shastri,9th edition 1995,20th chaper 128-129,page405, Chaukhmba bharti prakashan, Varanasi,20th chaper 128129,page-405

3.Dravyagunashastram,

Drvayagunashastram of Vd.G.A.Fadake edited by Vd.N.H.Joshi ayurved pathyakrama samiti prakashan 1960,page 312, number. 135

4.Ayurvediya Shabdakosh Edited by Vaidya Venimadhav Joshi,by Narayan hari Joshi,Maharashtra rajya sahitya and sanskruti mandal,Mumbai, 1968,page $\underline{\text { no. } 225}$

5.Ayurve- prakasha,Ayurved-prakasha of Acharya Shree Madhav Edited with Vidyotini and arthaprakashini Sanskrit and hindi commentaries by Vaidya Gulraj Sharma Mishra,Chaukhmba bharti Academyu, Varanasi, $]^{\text {th }}$ chaper 118,page-79

6.Gharguti Aushadhe, GhargutiAushadhe by Vaidyatirtha Appashastri Sathe,edited by mrs. Shailaja sathe, $16^{\text {th }}$ edition,2003,page no.315

7.Ek matra vanspatika chiktsa pryoga,by Dr.b.v. ghokhale,Dhanwantari Kayachikitsa visheshank1959

8.Psoriasis,sign and symptoms available on Http:/en.wikepedia.org/wiki/psoriasis

9.Dr.haisook"s medicopedia,cortisol/glucorticoids/corti costeroids/actions and sideeffects available on

http://meticopedia.wordpress.com/2009 $\angle 1 / 17 /$ cortisolglucocorticoidscorticoidsactions-and-sideeffects. 